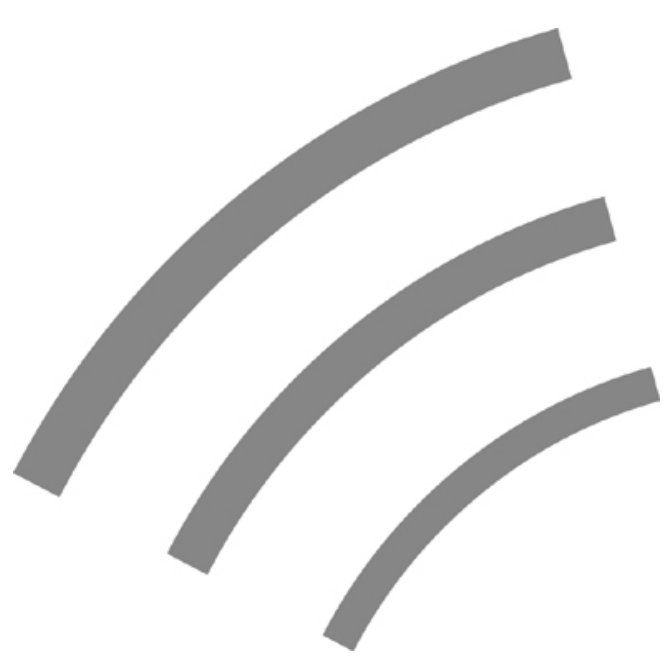

SCALES-paper N200407

The Role of Dissatisfaction and Per Capita Income in Explaining SelfEmployment across 15 European Countries

Niels Noorderhaven

Roy Thurik

Sander Wennekers

André van Stel

Zoetermeer, May, 2004 
The SCALES-paper series is an electronic working paper series of EIM Business and Policy Research. The SCALES-initiative (Scientific Analysis of Entrepreneurship and SMEs) is part of the 'SMEs and Entrepreneurship' programme, financed by the Netherlands' Ministry of Economic Affairs. Complete information on this programme can be found at www.eim.nl/smes-and-entrepreneurship

The papers in the SCALES-series report on ongoing research at EIM. The information in the papers may be (1) background material to regular EIM Research Reports, (2) papers presented at international academic conferences, (3) submissions under review at academic journals. The papers are directed at a research-oriented audience and intended to share knowledge and promote discussion on topics in the academic fields of small business economics and entrepreneurship research.

$\begin{array}{ll}\text { address: } & \text { Italiëlaan } 33 \\ \text { mail address: } & \text { P.O. Box } 7001 \\ & \text { 2701 AA Zoetermeer } \\ \text { telephone: } & +31793430200 \\ \text { telefax: } & +31793430201 \\ \text { website: } & \text { www.eim.nl }\end{array}$

The responsibility for the contents of this report lies with EIM. Quoting numbers or text in papers, essays and books is permitted only when the source is clearly mentioned. No part of this publication may be copied and/or published in any form or by any means, or stored in a retrieval system, without the prior written permission of EIM.

EIM does not accept responsibility for printing errors and/or other imperfections. 


\title{
THE ROLE OF DISSATISFACTION AND PER CAPITA INCOME IN EXPLAINING SELF-EMPLOYMENT ACROSS 15 EUROPEAN COUNTRIES
}

\author{
Niels Noorderhaven \\ Tilburg University and Institute for Research on Intercultural Cooperation, P.O. Box 80153, \\ 5000 LE Tilburg, the Netherlands, tel. +31-13-4662420, e-mail: n.g.noorderhaven@uvt.nl
}

\section{Roy Thurik}

Centre for Advanced Small Business Economics (CASBEC), Erasmus University Rotterdam, P.O. Box 1738, 3000 DR Rotterdam, the Netherlands, tel. +31 10 4081398, and EIM Business and Policy Research, P.O. Box 7001, 2701 AA Zoetermeer, the

Netherlands, tel. +31 79 3413634, e-mail: thurik@,few.eur.nl

Sander Wennekers

EIM Business and Policy Research P.O. Box 7001, 2701 AA Zoetermeer, the Netherlands, tel. +3179 3413634, e-mail: awe@eim.nl

\section{André van Stel}

EIM Business and Policy Research P.O. Box 7001, 2701 AA Zoetermeer, the Netherlands, tel. +31 79 3413634, e-mail: ast@eim.nl

\begin{abstract}
This paper deals with explaining the sizable differences in the rate of self-employment (business ownership) across 15 European countries in the period 1978-2000, within a framework of occupational choice, focusing on the influence of dissatisfaction and of per capita income. Using two different measures of dissatisfaction, in addition to the level of economic development and controlling for several other variables, we find that, in addition to a negative and significant impact of per capita income, dissatisfaction at the level of societies has a positive and significant influence on self-employment levels. Both dissatisfaction with life and dissatisfaction with the way democracy works are found to influence self-employment. It is concluded that these are proxies for job dissatisfaction and at the same time represent other negative 'displacements' known to promote self-employment. The findings indirectly point at the potential importance of push factors within the incentive structures of modern economies.
\end{abstract}

Keywords: comparative analysis of economies, cultural economics, entrepreneurship, macroeconomic analyses of economic development.

JEL codes: P52, Z1, M13, O11, O57.

Acknowledgement: We would like to thank Martin Carree, Simon Parker, Bert Smid, Gerrit de Wit and two anonymous referees for helpful comments. We also acknowledge the input of Geert Hofstede, Wim Verhoeven and Ralph Wildeman who contributed to a very early version. The present paper has been written in the framework of the research program SCALES which is carried out by EIM and financed by the Dutch Ministry of Economic Affairs.

Version: 26-3-2004 9:31

File name: Self-employment_and_Dissatisfaction_12C.doc 


\title{
THE ROLE OF DISSATISFACTION AND PER CAPITA INCOME IN EXPLAINING SELF-EMPLOYMENT ACROSS 15 EUROPEAN COUNTRIES
}

\begin{abstract}
This paper deals with explaining the sizable differences in the rate of self-employment (business ownership) across 15 European countries in the period 1978-2000, within a framework of occupational choice, focusing on the influence of dissatisfaction and of per capita income. Using two different measures of dissatisfaction, in addition to the level of economic development and controlling for several other variables, we find that, in addition to a negative and significant impact of per capita income, dissatisfaction at the level of societies has a positive and significant influence on self-employment levels. Both dissatisfaction with life and dissatisfaction with the way democracy works are found to influence self-employment. It is concluded that these are proxies for job dissatisfaction and at the same time represent other negative 'displacements' known to promote self-employment. The findings indirectly point at the potential importance of push factors within the incentive structures of modern economies.
\end{abstract}

\section{Introduction}

Scholars such as Chandler (1977), Galbraith (1967), and Schumpeter (1942) have convinced a generation of economists, social scientists and policy makers that the future was in the hands of large corporations, and that small business would fade away as the victim of its own inefficiencies. The justification for small businesses to survive seemed to be less on the grounds of economic efficiency than for employment and social and political purposes. More recently, however, the role ascribed to small business has changed. It is now also seen as a vehicle for entrepreneurship, contributing in terms of innovative and competitive power, rather than just employment and social and political stability (Morris, 2001). New evidence (Audretsch et al., 2001; Audretsch et al., 2002a; Audretsch and Thurik, 2000; Carree and Thurik, 1999 and 2003) suggests that entrepreneurship is one of the determinants of economic growth. Therefore, it should be perceived as something desirable for economic reasons, rather than as a social good that should be maintained at an economic cost.

Confronted with rising concerns about economic growth and competitiveness in global markets, governments have responded to this new evidence by making the stimulation of selfemployment a policy priority (Audretsch et al., 2001; Carree and Thurik, 2003; Geroski and Jacquemin, 1985; OECD, 1998). The question of how to realize this new policy agenda has led to the renewed recognition of two types of research questions. Firstly, why do some individuals seek self-employment, while others prefer to be an employee rather than a business owner? Secondly, why are more individuals self-employed in some countries than in others? The first question is systematically addressed in the literature on occupational choice (Blanchflower and Oswald, 1998; Brockhaus, 1982; De Wit, 1993; Kihlstrom and Laffont, 1979; Shapero and Sokol, 1982; Van Praag, 1999), whereas the second has been studied in a more ad hoc manner (Acs et al., 1994; Audretsch et al., 2002b; Blanchflower, 2000; Blanchflower and Meyer, 1994; Blau, 1987; Evans and Leighton 1989; 1990; Meager, 1992; Storey, 1991). Yet this latter question seems highly relevant, as the proportions of selfemployment differ strongly between countries, making it plausible that conditions or the way in which individuals respond to them also vary significantly.

Policies for stimulating entrepreneurship will have to take these factors into account. Additionally, policy makers should be aware of the limits of policy influence. It is important to know the extent to which factors are at play that are hardly susceptible to policy measures, such as cultural characteristics that have been shown to be very stable and changing only 
slowly over time (Hofstede, 2001).

Previous empirical investigations into the proportion of self-employment across countries have primarily focussed on the role of economic factors. Cultural variables have received only limited attention in this domain'. For instance, post-materialism, first coined by Inglehart (1977), describes the degree to which a society places immaterial life-goals such as personal development and self-esteem above material security. The role of post-materialism in explaining differences in self-employment between countries is dealt with in Uhlaner et al. (2002). Their paper confirms a negative relationship between post-materialism and selfemployment: countries with less materialistic values have lower self-employment rates in the labor force. Another example is uncertainty-avoidance, referring to the extent to which members of a culture feel threatened by uncertain or unknown situations (Hofstede, 2001). In strong uncertainty-avoidance countries people are assumed to have stronger emotional needs for rules and procedures, and to stay longer in a job at a particular organization. Uncertaintyavoidance also correlates negatively with need for achievement (Hofstede, 2001, p. 164). This suggests that in a strong uncertainty avoidance culture the step from wage-employment or unemployment to self-employment will be made less readily than in weak uncertaintyavoidance countries. This was indeed found in a study comparing self-employment in strong and weak uncertainty avoidance countries (Wennekers et al., 2001).

The objective of the present paper is to explore the role of satisfaction, or rather its inverse, dissatisfaction, as a determinant of aggregate self-employment. At the individual level, dissatisfaction has been shown to be a push factor in the decision to set up shop. But what is its influence at the macro level? The present research is the first to systematically investigate the role of dissatisfaction explaining self-employment across countries. We will use measures of aggregated dissatisfaction in combination with economic, social and demographic variables of 15 Member States of the European Union.

In section 2 of this paper we first look at motivational factors proposed to influence the willingness to be self-employed at the level of the individual actor, and consider the question of whether these factors can be 'aggregated' to the level of national economies. Next, we look at so-called 'reality' factors primarily influencing the resources and opportunities for entrepreneurship. Two kinds of hypotheses are developed. Firstly, we formulate hypotheses predicting the effect of two aggregated measures of dissatisfaction on the rate of selfemployment in a country. Secondly, we discuss the impact of the level of economic development on the rate of self-employment. In section 3 we also identify other economic variables as well as indicators of social and demographic structures that have to be controlled for when explaining self-employment at the level of national economies.

A major handicap in the analysis of international differences in self-employment is a lack of data. While research at the level of individuals can make use of large samples, data availability at the level of societies is severely restricted. In section 4 we therefore give ample attention to our data. In the present paper, time-series of aggregate levels of dissatisfaction in 15 European countries (taken from the Eurobarometer surveys) are used. Section 4 also gives details on the other data sets used to test our hypotheses, dependent and independent variables and controls, and on the statistical methods used. The results of the analysis are presented and discussed in section 5. Conclusions follow in section 6.

\section{Motivational factors, level of economic development and self-employment}

Recent years have brought an increasing body of literature on the determinants of self-

\footnotetext{
${ }^{1}$ When 'national culture and entrepreneurship' is the subject of research, it usually does not pertain to entrepreneurship rates at the country level, but to the characteristics of entrepreneurs or to corporate entrepreneurship (see Hayton, George and Zahra, 2002, for a review).
} 
employment and entrepreneurship at the country level. Most work in this area is restricted to economic determinants (Blau, 1987; Carree et al., 2002; Lucas, 1978; OECD, 2000; Parker, 1996). An exception is Wennekers et al. (2001), which addresses the influence of cultural variables by running separate regressions for countries with high and low uncertainty avoidance. Qualitative studies of entrepreneurship at the country level (Reynolds et al., 2000; Verheul et al., 2002; Wennekers, Uhlaner and Thurik, 2002) also draw upon other disciplines, such as psychology and sociology. The eclectic framework of occupational choice developed in Verheul et al. (2002) assumes that individuals valuate and compare the expected financial and non-pecuniary risks and rewards of self-employment versus wage-employment. This

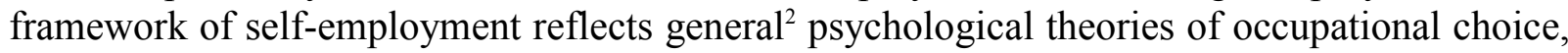
such as discussed by Vroom (1982). Here, anticipated satisfaction of expected pay, status, autonomy and other 'outcomes', weighted with their subjective probabilities, determine the 'valence' (Vroom, 1982, p. 15) of alternative occupations. The preferred occupation is defined as the occupation with the highest positive valence (Vroom, 1982, p. 53). Besides 'occupational preference', Vroom also distinguishes 'occupational choice', referring to the decision to attempt entering an occupation, and 'occupational attainment', referring to the occupation in which a person is presently working. The actual satisfaction that an occupation provides, which is called its 'value' (Vroom, 1982, p. 15), subsequently influences the stability of occupational attainment. In this approach both anticipated and actual satisfaction are among the driving forces in the occupational choice process.

In the present paper we focus on whether differences in the rate of self-employment at the country level are related to differences in satisfaction of the population at large. This focus is motivated as follows. First, as we will discuss below, at the individual level, the influence of dissatisfaction on the decision to start a business has often been established. Second, at the macro level, there is some intriguing evidence warranting a closer investigation of the role of dissatisfaction in relation to the level of self-employment, as the two variables appear to be positively correlated, as shown in Figure 1.

Insert Figure 1 about here.

In micro studies of entrepreneurship various types of dissatisfaction are used. Brockhaus $(1980,1982)$ states that dissatisfaction with previous work experience is closely related to the "entrepreneurial decision". He finds that self-employed individuals tend to be relatively strongly dissatisfied with the previous work itself, with supervision and with opportunities for promotion (but more satisfied with actual pay). Shapero and Sokol (1982, p. 79) assert: "Research data show that individuals are much more likely to take action upon negative information rather than positive, and the data on company formations support that conclusion". In their final model both pull and push factors contribute to the start-up of a business, but negative "displacements" such as forced emigration, being fired and being bored or angered predominate. Dyer (1994, p. 10) cites several other studies showing that people are more likely to start their own enterprises when they face a lack of opportunities for viable careers in existing organizations.

This all fits with what psychology tells us about motivation. In particular, individuals with a high sense of self-efficacy are activated by self-dissatisfaction, i.e., when they do not attain their goals. This spurs efforts to bring outcomes in line with their value standards (Bandura and Cervone, 1983). Vroom (1982, p. 175) infers from his model "... that job satisfaction should be related to the strength of the force on the person to remain in his job" or

\footnotetext{
${ }^{2}$ For a specific utility (or 'psychic satisfaction') maximization model of career choice with respect to entrepreneurship, see Douglas and Shepherd $(1999,2002)$.
} 
put otherwise "... that job satisfaction and turnover are negatively related to one another". Consequently, it is no surprise that dissatisfaction is one of the most important predictors of job mobility (Vroom, 1982; Mobley, 1982; Lee, 1988; Dailey and Kirk, 1992). Dissatisfaction as a motive for self-employment has also been confirmed in survey studies concerning start-ups. Huisman and De Ridder (1984), for instance, report that frustrations with previous wageemployment, unemployment, and personal crises are among the most-cited motives of a large sample of entrepreneurs in eleven different countries. More recently, Van Uxem and Bais (1996) found that about 50\% of almost 2000 starting Dutch entrepreneurs mentioned dissatisfaction with their previous job among their motives to start a business, although some pull factors were mentioned even more frequently. Hence, at the level of the individual various kinds of dissatisfaction are conducive to job mobility and the propensity to become selfemployed.

It is tempting to generalize these findings to the country level. However, the positive correlation between dissatisfaction and self-employment at the country level, as shown in Figure 1, might also originate from self-employed people being relatively dissatisfied with their jobs or their lives. This reversed causality, self-employment causing low satisfaction, is however ruled out by ample empirical evidence. In many studies (Blanchflower and Oswald, 1998; Bradley and Roberts, 2004; Frey and Benz, 2002; OECD, 2000; several studies cited by Jamal, 1997) the job satisfaction of self-employed is, on average, found to be higher or at least not lower than that of salaried employees. This seems to be the case in spite of longer work hours, poorer working conditions, heightened job stress and higher risk (OECD, 2000; Bradley and Roberts, 2004). Apparently, these are compensated by other factors such as autonomy and the possibility of becoming wealthy. Given the strong positive correlation between dissatisfaction and self-employment at the country level, it is likely that the push effect of actual dissatisfaction on the number of business start-ups is enhanced by a pull or demonstration effect of the self-employed being relatively satisfied with their jobs, boosting the anticipated satisfaction of entrepreneurship. ${ }^{3}$

Most studies investigating the role of motivational determinants of the choice for selfemployment pertain to the individual level. Its validity at the country level is underresearched in the entrepreneurship literature. Our research question is whether the relationship found at the individual level is valid at the societal level: countries where people are generally less satisfied with wage employment have a higher self-employment rate than other countries. To our knowledge no aggregate country data on job-dissatisfaction are available. In the present paper we use other aggregated dissatisfaction data to test for the assumed relationship. For reasons of statistical availability we use the following two indicators of dissatisfaction: dissatisfaction with life, and dissatisfaction with the way in which democracy works. Dissatisfaction with life (as reported in the Eurobarometer surveys) is a general concept and may be influenced by many different factors, like those mentioned by Huisman and De Ridder (1984). This kind of dissatisfaction may depend upon personal factors as well as factors in the environment of the individual. Vroom (1982, p. 161) cites several empirical studies showing that "The worker dissatisfied with his job, in contrast, is often ... generally unhappy and dissatisfied". Brayfield et al. (1957), as cited by Vroom (1982), add the insight that this holds more strongly for employed men than among employed women. Hence, we expect life-dissatisfaction to be positively related with job-dissatisfaction and thus with self-employment. Dissatisfaction with the way democracy works (also taken from the Eurobarometer), refers to the self-expressed degree of dissatisfaction of an individual with the way democracy in his or her country works. Dissatisfaction with the way democracy in one's country works is a more outward-directed kind of dissatisfaction than life-dissatisfaction. Although it may be related to the actual quality

\footnotetext{
${ }^{3}$ Nonetheless, the positive effect of self-employment on satisfaction may cause some countervailing 'statistical' influence on the overall level of dissatisfaction, proportional to the share of self-employment in the labor force.
} 
of the democracy in a particular country, we assume that it also conveys general information about the level of satisfaction of an individual with his or her environment, including the work environment. Given the empirical correlation between life and job satisfaction at the individual level, this seems likely. Hence, a positive relationship between dissatisfaction with democracy and self-employment is also expected.

At the same time we expect that dissatisfaction with life and/or with democracy may also pick up other relevant 'negative displacements' besides job dissatisfaction, such as being a refugee, belonging to an ethnic minority, being insulted, being fired or generally being an 'outsider', that Shapero and Sokol (1982) consider to have a strong positive effect on business start-ups. Our first hypothesis reads:

Hypothesis 1: Higher levels of dissatisfaction with life and/or with democracy in a country are conducive to higher rates of self-employment.

We further assume that occupational choice is not determined, however, by 'motivational factors' alone, but also depends on so-called 'reality factors' (Vroom, 1982, p. 62). Occupational choices (using this term in a broad way, including occupational attainment) may differ from occupational preferences because expectations may prove false, as a result of insufficient abilities, costs of training, or a lack of job vacancies. With respect to the choice between self-employment and wage employment the 'eclectic framework' by Verheul et al. (2002) analogously distinguishes between preferences, abilities, resources and opportunities. In their framework preferences represent the motivational factors, while abilities, resources and opportunities are the reality factors. Many of these latter factors, particularly resources and opportunities, depend upon economic phenomena such as the level of economic development ${ }^{4}$. Hence, to establish whether dissatisfaction influences the rate of self-employment we must also take economic variables into account.

First, we will discuss the relationship between self-employment rates and the level of economic development (prosperity) as measured by per capita income. It has been observed in various studies that the self-employment rate tends to decrease as economies become more developed (Kuznetz, 1966; Schultz, 1990; Bregger, 1996). This trend can be observed in crosssection data by comparing countries at different levels of economic development and in aggregate time-series data spanning long periods of time for several countries (Blau, 1987: 445). A low level of prosperity coincides with a low wage level, implying little pressure to increase efficiency or the average scale of enterprise. Small enterprises in agriculture, crafts and retail trade are dominant in such an economy. A major route for ambitious wage earners to increase their income is to set up shop and become an entrepreneur. Economic development subsequently leads to a rise in wages, which stimulates enterprises to work more capitalintensively, to save on labor and to reap economies of scale. A decline in self-employment is thus consistent with the exploitation of scale economies as wages grow and markets expand during the course of economic development, with a decline of the share of agriculture and with specialization of labor possible in the emerging large firms (Blau, 1987: 446). At the supply side of the labor market, an additional effect of rising real wage levels is an increased attraction of wage-employment. Put otherwise, the opportunity cost of self-employment increases relative to the return, inducing marginal entrepreneurs to become employees (Lucas, 1978). Iyigun and Owen (1998) argue that fewer individuals are willing to risk becoming an entrepreneur as more secure professional earnings rise with economic development.

This trend towards lower rates of self-employment may weaken, or even be reversed at a still later stage of economic development when differentiation of consumer demand increases

\footnotetext{
${ }^{4}$ In the short run, the stage of the business cycle also plays a role.
} 
and services become more important, creating new opportunities for self-employment. This partly explains the present resurgence of self-employment in some of the most highly developed economies. Furthermore, information technology and the differentiation of markets (niches) lead to new diseconomies of scale. An increased emphasis on subcontracting, partly related to globalization, may reinforce this process (Blau, 1987; Acs et al., 1994; Bais et al., 1995; Carree et al., 2002). However, information technology and globalization are worldwide phenomena (Audretsch and Thurik, 2000 and 2001) and these effects are thus hardly connected to a country's level of prosperity. Ceteris paribus, we still expect to find a negative relationship between prosperity and the self-employment rate $^{6}$. This gives rise to our second hypothesis:

Hypothesis 2: Higher levels of economic development (prosperity) in a country will lead to lower rates of self-employment.

\section{Control variables}

\section{Unemployment}

When testing the two hypotheses formulated above, we also want to take account of the relationship between unemployment and the propensity of individuals to enter selfemployment. This relationship is not straightforward. Unemployment (or the threat of it) basically acts as a push factor for self-employment (Evans and Leighton, 1990; Acs et al., 1994; Foti and Vivarelli, 1994; Audretsch and Thurik, 2000). In comparison with wageemployed persons, the opportunity costs for unemployed persons to become self-employed are relatively low, and this will favor their choice for self-employment. Of course, social security benefits and labor market regulation also determine these opportunity costs. The occupational choices of unemployed persons also relate to their skills and resources, and to the market opportunities available to them. On the whole, only a small proportion of the unemployed will actually become self-employed. ${ }^{7}$

On the other hand, high unemployment may be connected with an economic depression, which makes prospects for setting up a new business bleak and may cause disillusionment (Storey, 1991). However, unemployed may still (feel forced to) choose for self-employment, albeit in the form of 'marginal entrepreneurship'. It is difficult to say beyond which critical level of unemployment this discouragement effect is strong enough to reverse the sign of the unemployment variable.

\section{Earning differentials}

Another economic factor we will take into account is earning differentials between selfemployment and wage-employment. Potential profits are one obvious reason to set up shop or to shift from wage-employment to self-employment. Individuals are assumed to compare expected profits and wages when weighing the attractiveness of self-employment versus wageemployment. This income choice model of self-employment dates back as far as Knight (1921). More recently Murphy et al. (1991) propose a relationship between earning differentials and the allocation of talent across business ownership and wage-employment. In

\footnotetext{
${ }^{5}$ The influence of autonomous factors on the resurgence of self-employment, including a possible impact of a general trend towards deregulation in the 1990's and of business cycle effects, will be approximated in this study by the use of year-dummies.

${ }^{6}$ Carree et al. (2002) investigate several functional forms for the relationship between self-employment and per capita income.

${ }^{7}$ For a quantitative analysis of self-employment inflows, see Meager (1992).
} 
their model, if there are too many workers and too few entrepreneurs, the real wage will be low, "and so the best workers want to switch to entrepreneurship". Furthermore, Acemoglu (1995) provides a theoretical model of the impact of both pecuniary and non-pecuniary reward structures on occupational choices. Evans and Leighton (1990) and Foti and Vivarelli (1994) find empirical support for high profits as a pull factor for entering self-employment. See Santarelli and Sterlachini (1994) for partly conflicting evidence about the impact of profits and wages on business start-up rates in Italian manufacturing. A different argument is that selfemployment is inherently risky and "there is a positive probability that entrepreneurial activity will result in failure" (Iyigun and Owen, 1998, p. 455). An individual must weigh the prospect of potential high profits with the risk and uncertainty associated with self-employment. If countries differ in business risks or in risk aversion, this may be a cause for international differences in the impact of earning differentials on the rate of self-employment. Visee and Zwinkels (1999) find some empirical evidence of the differential importance that wage earners striving for self-employment attach to income security (and for its influence on their decision tot start part-time or full-time). All in all, at the aggregate level we expect a positive influence of income differentials on the number of self-employed.

\section{Labor participation of women}

When testing for the relationships expressed in our hypotheses, we will also control for the labor participation of women. In most Western countries, women in the labor force show substantially lower self-employment rates than men. Under the assumption of constant female/male self-employment differentials over time, a growing participation of women in the labor market implies a decreasing share of self-employment in the labor force (Acs et al., 1994).

\section{Population density}

The population density of a country might also influence its self-employment rate. Every region needs a minimum supply of facilities in the trade and handicraft industries for the population to 'survive'. Therefore, thinly populated areas with widely dispersed small villages will have relatively many small retail outlets and workshops. Conversely, urban areas will give rise to economies of scale through which small-sized entrepreneurship in retailing comes under pressure (Bais et al., 1995). On the other hand, networks and other supply side factors in urban areas are conducive to new entrepreneurship in many service industries. The sign of this control variable is not a priori clear.

\section{Data and method}

The dependent variable in this study is the rate of self-employment (business ownership) within a country at a certain point in time. This variable is operationalized as the number of self-employed (excluding agriculture, hunting, forestry and fishing), divided by the total labor force of a country and is collected for all the even years in the period 1972-2000. This data base is set up by EIM and is called Compendia 2000.2. Among the 23 countries covered by this data set are the European countries for which Eurobarometer dissatisfaction data are available. The economic indicators used in this study are labor income share, unemployment, per capita income, female labor share and population density. The labor income share of a country is defined as the share of labor income (including the imputed compensation of self-employed for their labor contribution) in the net national income (i.e., excluding capital consumption). Labor income shares are a pragmatic proxy for earning differentials between wage-employment and self-employment. The higher the labor income share, the smaller the share of the national income made up by profits, and hence the less attractive it is to become self-employed. 
Unemployment is expressed as a percentage of the total labor force of a country in a given year. ${ }^{8}$ Per capita income or GDP per capita is measured in constant prices of 1990. Furthermore, purchasing power parities in US \$ of 1990 are used to make the monetary units comparable between countries. The female labor share is the percentage of women in the total labor force. Population density, finally, is expressed as the number of people per square kilometer in a country.

The data were collected using several sources. The main sources are: OECD Main Economic Indicators, various versions; OECD Labour Force Statistics, versions 1970-1990 and 1981-2001; and OECD National Accounts, versions 1960-1994, detailed tables, and 19881998, detailed tables. However, for a number of variables such as self-employment, unemployment, and labor force, data were incomplete. We have completed these data using ratios derived from various other sources. Furthermore, EIM made a unified data set of selfemployment, which was necessary as in OECD Labour Force Statistics, the main source for self-employment in EIM's Compendia data base, the self-employment definitions are not fully compatible across countries. In some countries business owners are defined as individuals owning a business that is not legally incorporated. In other countries, owner/managers of an incorporated business (OMIBs) who enjoy profits as well as a salary are considered owners too. There are also countries that classify a part of the OMIBs as self-employed and another part as employee. This results from a different set-up of labor force surveys in different countries. This topic is dealt with in more detail in Chapter 5 of OECD Employment Outlook June 2000 (OECD, 2000). Business owners in the present paper are defined to include OMIBs. For the countries not following this definition, EIM made an estimation of the number of OMIBs using information derived from The European Observatory for SMEs (KPMG/ENSR, 2000). Another difference in definition is that for some countries unpaid family workers are included in the self-employment data as well, mostly for early years. For these years, the unpaid family workers were removed from the data by using ratios from more recent years for which separate data on unpaid family workers are available. Data on the labor force are also from OECD Labour Force Statistics. Again, some missing data have been filled up from various other sources. This work has resulted in a unified data set of self-employment (COMPENDIA 2000.2, COMparative ENtrepreneurship Data for International Analysis), which includes the owners of both the incorporated and the unincorporated businesses but excludes the unpaid family workers. More information on this data set can be found in Van Stel (2003). ${ }^{9}$

The data on dissatisfaction are based upon the Eurobarometer surveys (Eurobarometer: Public opinion in the European Community, ISSN 1012-2249, Brussels: CEC), and are available for the 15 Member States of the European Union. Dissatisfaction with life is measured as the percentage of respondents indicating to be 'not at all satisfied with life' or 'not very satisfied with life'. Dissatisfaction with democracy as the percentage indicating to be 'not at all satisfied with the way democracy works' or 'not very satisfied with the way democracy works'. We have no full data set at our disposal. For nine countries (Belgium, Denmark, France, Germany, Ireland, Italy, Luxembourg, the Netherlands, and the United Kingdom) we have dissatisfaction data available regarding 12 years (1976-1998; even years), for one country (Greece) regarding 10 years (1980-1998), for two countries (Portugal and Spain) regarding 8 years (1984-1998), and for three countries (Austria, Finland, and Sweden) regarding two years

\footnotetext{
${ }^{8}$ We use the concept of 'standardised unemployment rates', as practiced by OECD.

9 Another important data source for comparing entrepreneurship rates across countries is the Global Entrepreneurship Monitor (GEM). In 2002 comparative data for various entrepreneurship measures were available for 37 countries (Reynolds et al., 2002). However, as the first GEM assessment was held in 1999, it will take several years before a time-series analysis over a considerable length of time can be performed using GEM data.
} 
(1996-1998)..$^{10}$ Because of the varying extent of (dissatisfaction) data availability across countries, we carry out our empirical analyses using an unbalanced data panel. The correlation matrix of the variables used in our study is in Table 1. The correlations are computed using data for the years 1976, 1984, 1990 and 1998 (48 observations). ${ }^{11}$

Insert Table 1 about here

We use regression analysis (ordinary least-squares) to test our hypotheses. We regress self-employment on the two metrics of dissatisfaction and on GDP per capita, using labor income share, unemployment, female labor share, population density and some time dummies as controls. In order to assess the effect of dissatisfaction we first regress self-employment on the economic variables only. After that, we include life-dissatisfaction and dissatisfaction with democracy in two separate analyses, the reason for this being the strong positive correlation between the two kinds of dissatisfaction, the strongest between any pair of independent variables (see Table 1). In our regressions, we use only the data from 1978, 1986, 1992 and 2000 (for the dependent variable) and from 1976, 1984, 1990 and 1998 (for the independent variables). By using 8 -year intervals we avoid autocorrelation problems. ${ }^{12}$ All in all, we have 48 data points, corresponding to the maximum availability of the dissatisfaction data for the four mentioned years in our unbalanced panel. In order to control for systematic differences across years, dummy variables are introduced for 1986, 1992 and 2000 (1978 being the reference year). ${ }^{13}$

\section{Results}

Results are given in Table 2. We first discuss the results of the regression without the dissatisfaction variable (Model 1).

Insert Table 2 about here

The results for Model 1 show that GDP per capita has a negative and significant effect on self-employment. This result fully conforms to expectations as formulated in hypothesis 2 . The economic control variables labor income share and unemployment rate have insignificant effects, and of the other control variables, only female labor share has significant (negative) sign, while population density is insignificant. The three dummy variables for the years 1986, 1992 and 2000 are significantly positive, with dummy coefficients increasing over time. This pattern shows that in the time period considered there has been an increase in self-employment not fully explained by our independent variables. This autonomous effect on self-employment may be due to general trends such as globalization, the information technology revolution and deregulation.

In Models 2 and 3, dissatisfaction with life respectively dissatisfaction with democracy

\footnotetext{
${ }^{10}$ In this paper, we use data for West-Germany until 1988, and data for (re-unified) Germany from 1990 onwards.

11 These are the years for the independent variables. Because we use a two-year lag in our model, these years correspond to 1978, 1986, 1992 and 2000 for the dependent variable. For the latter three years we will include time dummies in our model. These dummies are also included in Table 1.

${ }^{12}$ Note that there is a 6-year interval between 1984 and 1990. We did not use 1982 because this would result in a loss of two observations, as the earliest year for which dissatisfaction data are available for Portugal and Spain is 1984.

13 The introduction of time dummies while using an unbalanced panel is justified as the extent of 'unbalancedness' over time is limited. The numbers of observations (countries) available for 1986, 1992 and 2000 are 12,12 and 15 , respectively.
} 
are entered into the equation. Both dissatisfaction variables have positive and significant coefficients. The significance level (but not the sign) of a number of other variables changes, when either dissatisfaction with life or dissatisfaction with democracy is taken into account. Given the modest sample size, this is not surprising. In the regression with life dissatisfaction (Model 2), the standard errors of all other variables are higher compared to the regression with democracy dissatisfaction (Model 3). This is not surprising given the strong negative correlation between life dissatisfaction and GDP per capita. ${ }^{14}$ The results of Model 3 are particularly interesting, as dissatisfaction with democracy is less strongly correlated with GDP per capita. This regression also yields the highest adjusted R-squared (.714). ${ }^{15}$

All in all, the results in Models 2 and 3 offer strong support for hypothesis 1: both types of dissatisfaction, life dissatisfaction as well as dissatisfaction with the way in which democracy works, are positively and significantly related to the rate of self-employment. This is the case controlling for the most important 'economic' factors mentioned in the literature. There is also strong support for hypothesis 2: higher levels of economic development (reflected in a higher GDP per capita) are associated with lower levels of self-employment. Even when taking account of the (varying) correlation between (different types of) dissatisfaction and per capita income, both dissatisfaction and the level of economic development are found to have a separate effect on self-employment.

Our first control variable, unemployment, is negatively, rather than positively, related to self-employment (although this result is significant only in Model 3). The negative influence of unemployment suggests a bigger impact of (high) unemployment as an indicator of decreasing business opportunities than of unemployment as a push factor, where the latter effect is limited by the relatively generous social security system in many EU-countries. The negative effect may also be partly due to reversed causality. There is assumed to be a two-way causation between changes in the level of entrepreneurship and that of unemployment - a "Schumpeter" effect of entrepreneurship reducing unemployment and a "refugee" effect of unemployment stimulating entrepreneurship. Audretsch et al. (2001) estimate a two-equation model where changes in unemployment and in the number of business owners are linked to subsequent changes in those variables for a panel of 23 OECD countries over the period 1974-1998. The existence of two distinct and separate relationships between unemployment and entrepreneurship is identified, including significant "Schumpeter" and "refugee" effects. They show that the negative "Schumpeter" effect is bigger than the positive "refugee" effect. This might contribute to the negative effect found in the present analysis.

There is no support for an influence of the labor income share. This variable shows an (insignificant) positive sign, contrary to our expectations. Perhaps the labor income share is too crude an (inverse) measure for business profitability. Furthermore, the positive sign might also be partly due to reversed causality. Too large numbers of self-employed may cause average profit levels to be low. A glut of self-employment will cause the average scale of operations to remain below optimum, resulting in large numbers of 'marginal' entrepreneurs, who hardly make any profits (Carree et al., 2002). ${ }^{16}$

\footnotetext{
${ }^{14}$ Note, however, that results from Model 2 are 'correct' from a multicollinearity point of view as the maximum value of the variance inflation factor is 4.63, corresponding to a tolerance level of .216.

${ }^{15}$ When both dissatisfaction measures are included in a single regression model (not reported in Table 2), the adjusted R-squared is .721. Estimated parameters and significance levels of the independent variables are similar to those of model 3, except for dissatisfaction with democracy. As mentioned, this is due to the strong correlation between the two dissatisfaction variables. In the combined specification the coefficient is .070 for dissatisfaction with life (t-value 1.4) and .097 for dissatisfaction with democracy (t-value 3.1). The F-value for this specification is 13.1 which is significant at .001 level.

${ }^{16}$ In this respect, Greece is a striking example. Greece combines a high self-employment rate with a labor income share above one, indicating that the imputed wage income for the self-employed persons is higher than the actual total income of the self-employed.
} 
Of the other control variables, the effect of population density is consistently positive in the regressions (but only once significantly so). An explanation may be that in the most urbanized member states of the European Union positive network effects on birth rates of new firms prevail, increasing the rate of self-employment. A different explanation may be that population density is too crude a measure for variations in economic activities due to the occurrence of both densely populated areas and sparsely populated areas within one country. The coefficient of female labor share is consistently negative, as expected, and significant in all three models. The results for the year dummies are roughly similar in all three models.

We perform several tests of robustness. First, we investigate to which extent the main estimation results in Table 2 are affected by three possible 'outlier' countries. From Figure 1 we see that Greece, Italy and Portugal combine high self-employment rates with high levels of dissatisfaction. It might be that the positive effects found for dissatisfaction in Table 2 are merely valid for these three countries. However, computing the regressions excluding these three countries, we still find significantly (.001 level) positive effects of both life dissatisfaction and democracy dissatisfaction. The effects are somewhat smaller though: the coefficients are .13 (life dissatisfaction; Model 2) and .09 (democracy dissatisfaction; Model $3)$.

Second, we investigate whether results are different if we measure dissatisfaction in terms of only the people responding to be 'not at all' satisfied with life or democracy (instead of 'not at all' or 'not very' satisfied). It might be that people responding to be 'not very' satisfied with life or democracy are less inclined to start their own business than people responding to be 'not at all' satisfied. To test this we computed separate regressions using the separate percentages of people responding to be 'not at all' and 'not very' satisfied. Both for dissatisfaction with life and for dissatisfaction with democracy the estimated parameters remain positive and significant at .001 level, irrespective of whether the 'not at all' or the 'not very' categories are used. We conclude that our regression results are robust in this respect.

Third, we test the robustness for linear versus non-linear specifications. Perhaps the effect of dissatisfaction is smaller when the numbers of dissatisfied citizens are higher. This might be the case if the high dissatisfaction levels signal higher proportions of people who are discouraged to take their life in their own hand and start a business. To test this we computed regressions using the natural logarithm of the dissatisfaction variables. We do not find large differences compared to the results in Table 2. The effects of the dissatisfaction variables are (remain) positive and highly significant. R-squared values are also similar. Hence, we cannot discriminate statistically between a linear and a non-linear effect.

In all test specifications, the effect of per capita income remains negative and highly significant. We conclude that our results are robust to the exclusion of 'outlier countries', and to different specifications of the dissatisfaction variables.

\section{Conclusion}

The determinants of self-employment constitute a complex phenomenon (Audretsch et al., 2002b). So far, investigations of nation-wide differences have concentrated largely on the role of economic variables, particularly of per capita income. The low explanatory power of these economic variables, as well as the relative stability of differences in the rate of selfemployment across nations, suggest the additional influence of cultural and institutional variables. The present paper takes the socio-psychological variable 'dissatisfaction' into account and concludes that, across nations, dissatisfaction with society and with life in general seems to be a distinguishing factor. Countries with relatively more people who are dissatisfied with the society they live in and/or who have a lower overall life satisfaction, have a higher proportion of self-employed. This conclusion is robust when controlling for other explanatory 
variables. In addition to the positive influence of dissatisfaction, and in spite of some degree of multicollinearity, the negative influence of the level of economic development as predicted by theory, is confirmed. The increasing coefficients of the three consecutive year dummies suggest that during the 1990's general trends such as globalization, the ICT revolution and deregulation may have had a positive effect on the rate of self-employment, while an additional business cycle effect in the year 2000 is certainly not ruled out. Unemployment is found to have a negative rather than a positive influence, at least in the 15 European countries considered in this study.

The fact that nations with a higher average level of dissatisfaction have a higher proportion of self-employed should not be taken as a sign that the average self-employed is more dissatisfied than the average wage-employed. As discussed in section 2, the opposite seems to be true. The conclusion to be drawn is that if more people in a country feel dissatisfied with their life and with the way democracy works, this increases the chance that they will seek self-employment. Those who do so tend to improve their life and job satisfaction over those who do not (Hofstede, 1998).

Our study has several limitations that should be borne in mind when interpreting the results. First, an obvious complication with our setup for explaining self-employment at the country level is that per capita income, unemployment and earning differentials do not only make up 'economic' factors but may also influence dissatisfaction. Due to these interrelationships, the 'final' effect of the economic factors may be larger than their partial influence found in our multiple regressions. Second, one must be prudent in extrapolating the conclusions found in this study to worldwide relationships. The results pertain to Western European countries. It remains to be investigated whether the relationship still exists when other (e.g., developing) countries are included. Third, we have looked at a particular time period, and not all the relationships we have found may hold in future times. The recent revival of the rate of self-employment that occurred in most countries in our sample (but not in Denmark, France and Luxembourg, that show a continued decline), after a nearly continuous decline since at least the $19^{\text {th }}$ Century, mostly happened in the second half of the period covered by our sample (however, in Ireland, the UK and Italy the revival occurred over most of our sample period). This reversal of the trend has coincided with fundamental economic changes including globalization and the ICT revolution. Fourth, although we have included several control variables, we obviously did not control for all factors that may influence the level of self-employment. For instance, we did not take into account the sector composition of the economies of the countries included in the study, the age composition of the labor force, and the level of education (Blanchflower and Meyer 1994; Evans and Leighton 1989). Fifth, our present model estimates the effect of dissatisfaction on the total self-employment rate, whereas probably dissatisfaction primarily impacts on new business formation and thus influences total self-employment indirectly and with a time lag. The present model pragmatically deals with this problem by specifying a two-year lag for all explanatory variables. Future research may take this into account by using a distributed $\operatorname{lag}^{17}$ or by specifying an equation in first differences within the context of an error correction model (see Carree et al., 2002).

At first sight, our findings offer only limited guidance to politicians who would like to stimulate self-employment. The promotion of dissatisfaction seems hardly a feasible policy option. However, some policy implications may emerge by linking our results to (other) considerations and empirical findings reported in the literature. First, when explaining

\footnotetext{
${ }^{17}$ A first attempt including a four-year lagged endogenous variable representing a distributed lag on the explanatory variables, confirms the positive effect of dissatisfaction and the negative effect of GDP per capita reported in the present paper.
} 
differences in self-employment rates it is customary to distinguish between 'pull' factors and 'push' factors (Stanworth and Curran, 1973). Pull factors make self-employment more attractive. Some examples are the perspective of independence and autonomy, the possibility to earn high profits, or the opportunity to evade taxes. Push factors make wage-employment and/or unemployment less attractive and thus 'push' people towards self-employment. Some examples are low wages, limited autonomy in a paid job, frugal social security benefits or lack of alternative ways to make a living. Viewed from within this context, our findings indirectly point at the importance of push factors in addition to pull factors ${ }^{18}$. This may induce policymakers to scrutinize the incentive structures ${ }^{19}$ in their economies, next to promoting and facilitating self-employment through counseling and information, through lower administrative and legal hurdles for business start-ups, and through loan guarantee schemes or specific tax breaks for young enterprises. Second, another policy implication arises by combining our findings with those of research on micro data. Research comparing self-employed with wageearners suggests that the former are more focused on individual responsibility and effort, and more strongly espouse an ethic of working hard (Beugelsdijk and Noorderhaven, 2004). These characteristics may make an individual more likely to respond to dissatisfaction by setting up shop. Hence, it may also be wise to consider how the educational system may contribute to the development of the entrepreneurial qualities of a country's population (Van der Kuip and Verheul, 2004). In this way, the chances that dissatisfaction becomes an engine of economic progress, rather than a source of inertia, may be increased.

\section{References}

Acemoglu, D. (1995). Reward structures and the allocation of talent, European Economic Review 39, 17-33.

Acs, Z.J., D.B. Audretsch and D.S. Evans (1994). The determinants of variations in selfemployment rates across countries and over time (unpublished manuscript).

Audretsch, D.B., M.A. Carree, and A.R. Thurik (2001). Does entrepreneurship reduce unemployment? Tinbergen Institute Discussion Paper TI01-074/3, Rotterdam: Erasmus University.

Audretsch, D.B., and A.R. Thurik (2000). Capitalism and democracy in the 21 st century: from the managed to the entrepreneurial economy, Journal of Evolutionary Economics 10, 17 34.

Audretsch, D.B., and A.R. Thurik (2001). What is new about the new economy: sources of growth in the managed and entrepreneurial economies, Industrial and Corporate Change 10, 267-315.

Audretsch, D.B., M.A. Carree, A.J. van Stel, and A.R. Thurik (2002a). Impeded industrial restructuring: the growth penalty, Kyklos 55, 81-98.

\footnotetext{
18 The relevance of push factors in addition to pull factors is confirmed by the findings of Parker and Robson (2003). For a panel of 12 OECD countries spanning the period 1972-1996, Parker and Robson investigate the determinants of self-employment utilizing recently developed panel unit root and cointegration techniques. Using original self-employment data from OECD Labour Force Statistics, they find a positive effect of personal income tax rates, and negative effects of employers' social security contributions and the unemployment benefit replacement rate.

${ }^{19}$ In many EU-countries the push effect of unemployment towards self-employment seems to be quite limited by a social security system that is both relatively generous and biased towards insuring the wage-employed, while the push effect embodied in wage-employment is limited by relatively strict labour market regulation.
} 
Audretsch, D.B., A.R. Thurik, I. Verheul, and A.R.M. Wennekers (eds.) (2002b). Entrepreneurship: Determinants and Policy in a European-US Comparison, Boston/Dordrecht: Kluwer Academic Publishers.

Bandura, A., and D. Cervone (1983). Self-evaluative and self-efficacy mechanisms governing the motivational effects of goal systems, Journal of Personality and Social Psychology 45, 1017-1028.

Bais, J., W.H.M. van der Hoeven, and W.H.J. Verhoeven (1995). Determinanten van zelfstandig ondernemerschap, Den Haag: OSA (in Dutch).

Beugelsdijk, S., and N.G. Noorderhaven (2004). Personality characteristics of self-employed; An empirical study, Small Business Economics, forthcoming.

Blanchflower, D.G. (2000). Self-employment in OECD Countries, Labour Economics 7, 471505.

Blanchflower, D.G., and B.D. Meyer (1994). A longitudinal analysis of the young selfemployed in Australia and the United States, Small Business Economics 6, 1-25.

Blanchflower, D.G., and A.J. Oswald (1998). What makes an entrepreneur? Journal of Labor Economics 16, 26-60.

Blau, D. (1987). A time series analysis of self-employment, Journal of Political Economy 95, 445-467.

Bradley, D.E. and J.A. Roberts (2004). Self-employment and job satisfaction: investigating the role of self-efficacy, depression, and seniority, Journal of Small Business Management 42, 37-58.

Brayfield, A.H., R.V. Wells, and N.W. Strate (1957). Interrelationships among measures of job satisfaction and general satisfaction, Journal of Applied Psychology 41, 201-205.

Bregger, J.E. (1996). Measuring self-employment in the United States, Monthly Labor Review, January/February, 3-9.

Brockhaus, R.H. (1980). The effect of job dissatisfaction on the decision to start a business, Journal of Small Business Management 18, 37-43.

Brockhaus, R.H. (1982). The psychology of the entrepreneur, in C.A. Kent, D.L. Sexton and K.H. Vesper (eds.), Encyclopedia of Entrepreneurship, Englewood Cliffs, NJ: PrenticeHall Inc, 39-57.

Carree, M.A., A.J. van Stel, A.R. Thurik, and A.R.M. Wennekers (2002). Economic development and business ownership: an analysis using data of 23 OECD countries in the period 1976-1996. Small Business Economics 19, 271-290.

Carree, M.A., and A.R. Thurik (1999). Industrial structure and economic growth, in Innovation, Industry Evolution and Employment, D.B. Audretsch and A. R. Thurik (eds.), Cambridge, UK: Cambridge University Press, 86-110.

Carree, M.A., and A.R. Thurik (2003). The impact of entrepreneurship on economic growth, in Handbook of Entrepreneurship Research, D.B. Audretsch and Z.J. Acs (eds.), Boston/Dordrecht: Kluwer Academic Publishers, forthcoming.

Chandler, A.D., Jr. (1977). The Visible Hand: The Managerial Revolution in American Business, Cambridge, MA: Harvard University Press.

Dailey, R.C., and D.J. Kirk (1992). Distributive and procedural justice as antecedents of job dissatisfaction and intent to turnover, Human Relations 45, 305-317.

De Wit, G. (1993). Models of self-employment in a competitive market. Journal of Economic Surveys 7, 367-397.

Douglas, E.J. and D.A. Shepherd (1999). Entrepreneurship as a utility maximizing response, Journal of Business Venturing 15, 231-251.

Douglas, E.J. and D.A. Shepherd (2002). Self-employment as a career choice: attitudes, entrepreneurial intentions, and utility maximization, Entrepreneurship Theory and Practice 26(3), 81-90. 
Dyer, W.G. (1994). Toward a theory of entrepreneurial careers, Entrepreneurship Theory and Practice 19(2), 7-21.

Evans, D.S., and L.S. Leighton (1989). The determinants of changes in US self-employment, 1968-1987, Small Business Economics 1, 111-119.

Evans, D.S., and L.S. Leighton (1990). Small business formation by unemployed workers, Small Business Economics 2, 319-330.

Foti, A., and M. Vivarelli (1994). An econometric test of the self-employment model: The case of Italy, Small Business Economics 6, 81-93.

Frey, B.S., and M. Benz (2002). Being independent is a great thing: subjective evaluations of self-employment and hierarchy, Working Paper No. 135, Institute for Empirical Research in Economics, University of Zurich.

Galbraith, J.K. (1967). The New Industrial State, Boston, MA: Houghton Mifflin.

Geroski, P.A., and A. Jacquemin (1985). Industrial change, barriers to mobility and European industrial policy, Economic Policy 1, 169-204.

Hayton, J.C., G. George and S.A. Zahra (2002). National culture and entrepreneurship: a review of behavioral research, Entrepreneurship Theory and Practice 26(4), 33-52.

Hofstede, G. (1998). Entrepreneurship in Europe, Maastricht/House of Europe: Schuman Lecture 1998, Studium Generale.

Hofstede, G. (2001). Culture's Consequences; Second Edition. Thousand Oaks: Sage.

Huisman, D., and W.J. de Ridder (1984). Vernieuwend Ondernemen. Utrecht: SMO (in Dutch).

Inglehart, R. (1977). The Silent Revolution: Changing Values and Political Styles among Western Publics, Princeton, NJ: Princeton University Press.

Iyigun, M.F., and A.L. Owen (1998). Risk, entrepreneurship, and human-capital accumulation, AEA Papers and Proceedings 88, 454-457.

Jamal, M. (1997). Job stress, satisfaction, and mental health: an empirical examination of selfemployed and non-self-employed Canadians, Journal of Small Business Management 35 (4), 48-57.

Kihlstrom, R.E., and J.J. Laffont (1979). A general equilibrium entrepreneurial theory of firm formation based on risk aversion, Journal of Political Economy 87, 719-748.

Knight, F. (1921). Risk, Uncertainty and Profit, Boston: Houghton Mifflin.

KPMG/ENSR (2000). The European Observatory for SMEs: Sixth Report, Zoetermeer: EIM Business and Policy Research.

Kuznetz, S. (1966). Modern Economic Growth: Rate, Structure, and Spread, New Haven: Yale University Press.

Lee, T.W. (1988). How job dissatisfaction leads to employee turnover, Journal of Business and Psychology 2, 263-271.

Lucas, R.E., Jr. (1978). On the size distribution of business firms, Bell Journal of Economics 9, 508-523.

Meager, N. (1992). Does unemployment lead to self-employment? Small Business Economics 4, 87-103.

Mobley, W.H. (1982). Employee Turnover: Causes, Consequences, and Control, Reading, MA: Addison-Wesley.

Morris, M.H. (2001). Entrepreneurship is economic development is entrepreneurship. Journal of Developmental Entrepreneurship 6 (3), v-vi.

Murphy, K.M., A. Shleifer, and R.W. Vishny (1991). The allocation of talent: implications for growth, The Quarterly Journal of Economics 106, 503-530.

OECD (1998). Fostering Entrepreneurship, the OECD Jobs Strategy, Paris: OECD.

OECD (2000). Employment Outlook, Paris: OECD.

Parker, S.C. (1996). A time series model of self-employment under uncertainty, Economica 63, 459-475. 
Parker, S.C., and M.T. Robson (2003), Explaining international variations in entrepreneurship: evidence from a panel of OECD countries, Entrepreneurship Research Series, No. 004, Durham, UK: Barclays Centre for Entrepreneurship, Durham Business School.

Reynolds, P.D., M. Hay, W.D. Bygrave, S.M. Cap, and E. Autio (2000). Global Entrepreneurship Monitor: 2000 Executive Report. Kauffman Center for Entrepreneurial Leadership at the Ewing Marion Kauffman Foundation.

Reynolds, P.D., W.D. Bygrave, E. Autio, L.W. Cox, and M. Hay (2002), Global Entrepreneurship Monitor, 2002 Executive Report, Wellesley, MA: Babson College.

Santarelli, E., and A. Sterlacchini (1994). New firm formation in Italian industry, Small Business Economics 6, 95-106.

Schultz, T.P. (1990). Women's changing participation in the labor force: a world perspective, Economic Development and Cultural Change 38, 457-488.

Schumpeter, J.A. (1942). Capitalism, Socialism and Democracy, New York: Harper and Row.

Shapero, A., and L. Sokol (1982). The social dimensions of entrepreneurship, in C.A. Kent, D.L. Sexton and K.H. Vesper (eds.), Encyclopedia of Entrepreneurship, Englewood Cliffs, NJ: Prentice-Hall Inc, 72-90.

Stanworth, M.J.K., and J. Curran (1973). Management Motivation in the Smaller Business, London: Gower Press.

Storey, D.J. (1991). The birth of new firms: does unemployment matter? Small Business Economics 3, 167-179.

Uhlaner, L., A.R. Thurik and J. Hutjes (2002). Post-materialism: a cultural factor influencing entrepreneurial activity across nations. Erasmus Research Institute for Management Report ERS-2002-62-STR, Rotterdam: Erasmus University.

Van der Kuip, I., and I. Verheul (2004), Early development of entrepreneurial qualities: the role of initial education, International Journal of Entrepreneurship Education 2, forthcoming.

Van Praag, C.M. (1999), Some classic views on entrepreneurship, De Economist 147, 311-335.

Van Stel, A.J. (2003). COMPENDIA 2000.2: a harmonized data set of business ownership rates in 23 OECD countries, EIM Research Report 200302, Zoetermeer: EIM Business and Policy Research.

Van Uxem, F.W., and J. Bais (1996). Het starten van een bedrijf; Ervaringen van 2000 starters. Zoetermeer: EIM Business and Policy Research (in Dutch).

Verheul, I., A.R.M. Wennekers, D.B. Audretsch, and A.R. Thurik (2002). An eclectic theory of entrepreneurship. In D.B. Audretsch, A.R. Thurik, I. Verheul and A.R.M. Wennekers (eds.), Entrepreneurship: Determinants and Policy in a European-US Comparison. Boston/Dordrecht: Kluwer Academic Publishers, 11-81.

Visee, H.C. and W.S. Zwinkels (1999). Van werknemer naar ondernemer; een hybride of directe start? Research Report 9907, Zoetermeer: EIM Business and Policy Research (in Dutch).

Vroom, V.H. (1982). Work and Motivation, Malabar, Florida: Robert E. Krieger Publishing Company.

Wennekers, A.R.M., N.G. Noorderhaven, G. Hofstede, and A.R. Thurik (2001). Cultural and economic determinants of business ownership across countries. In Frontiers of Entrepreneurship Research 2001, Babson College, MA: Center for Entrepreneurial Studies, 179190.

Wennekers, A.R.M., L.M. Uhlaner, and A.R. Thurik (2002). Entrepreneurship and its conditions: a macro perspective. International Journal of Entrepreneurship Education 1, 2564. 
Figure 1: Self-employment and dissatisfaction in 15 European countries, 1998

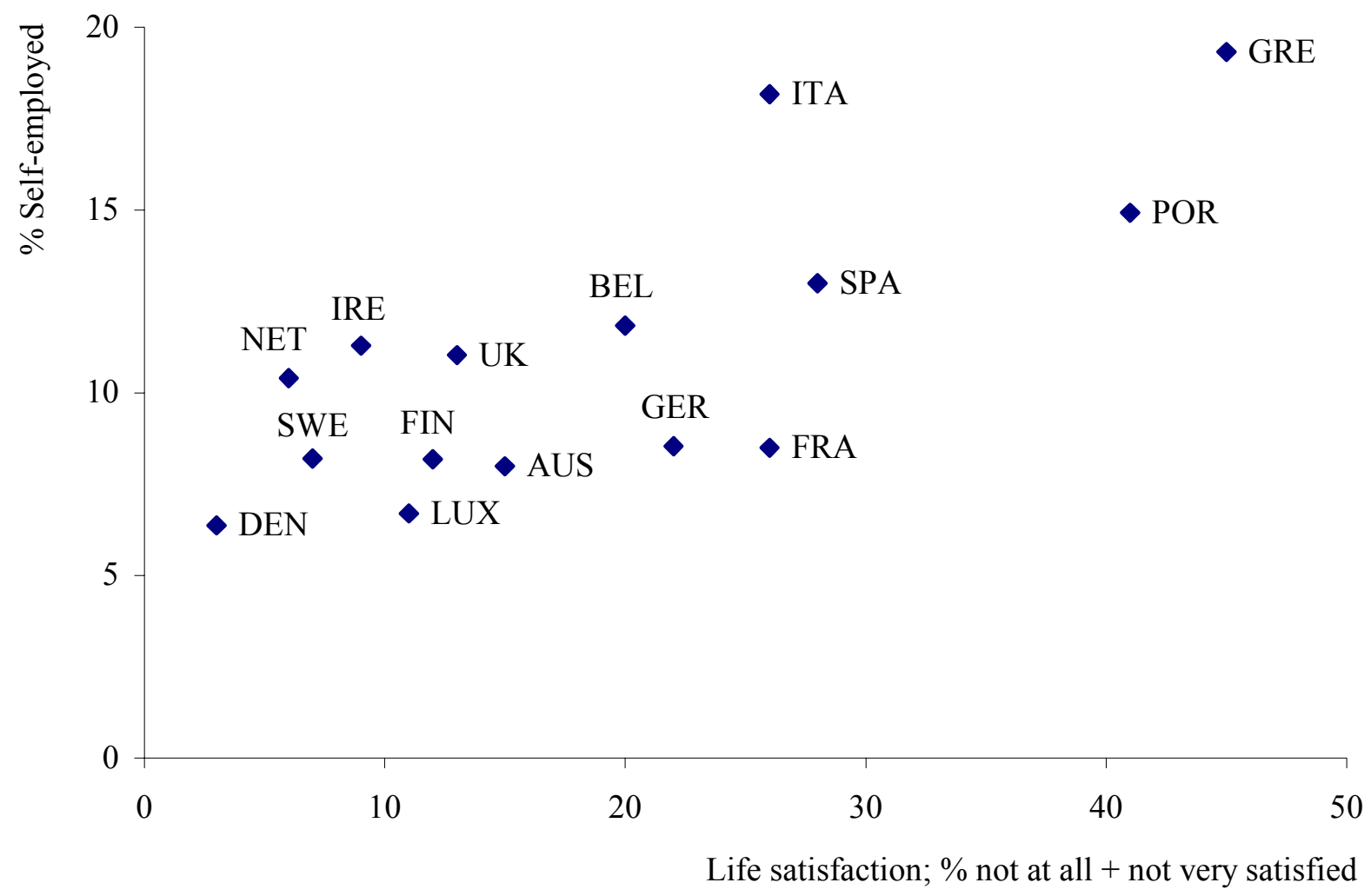

Source: Eurobarometer surveys and Compendia 2000.2. 


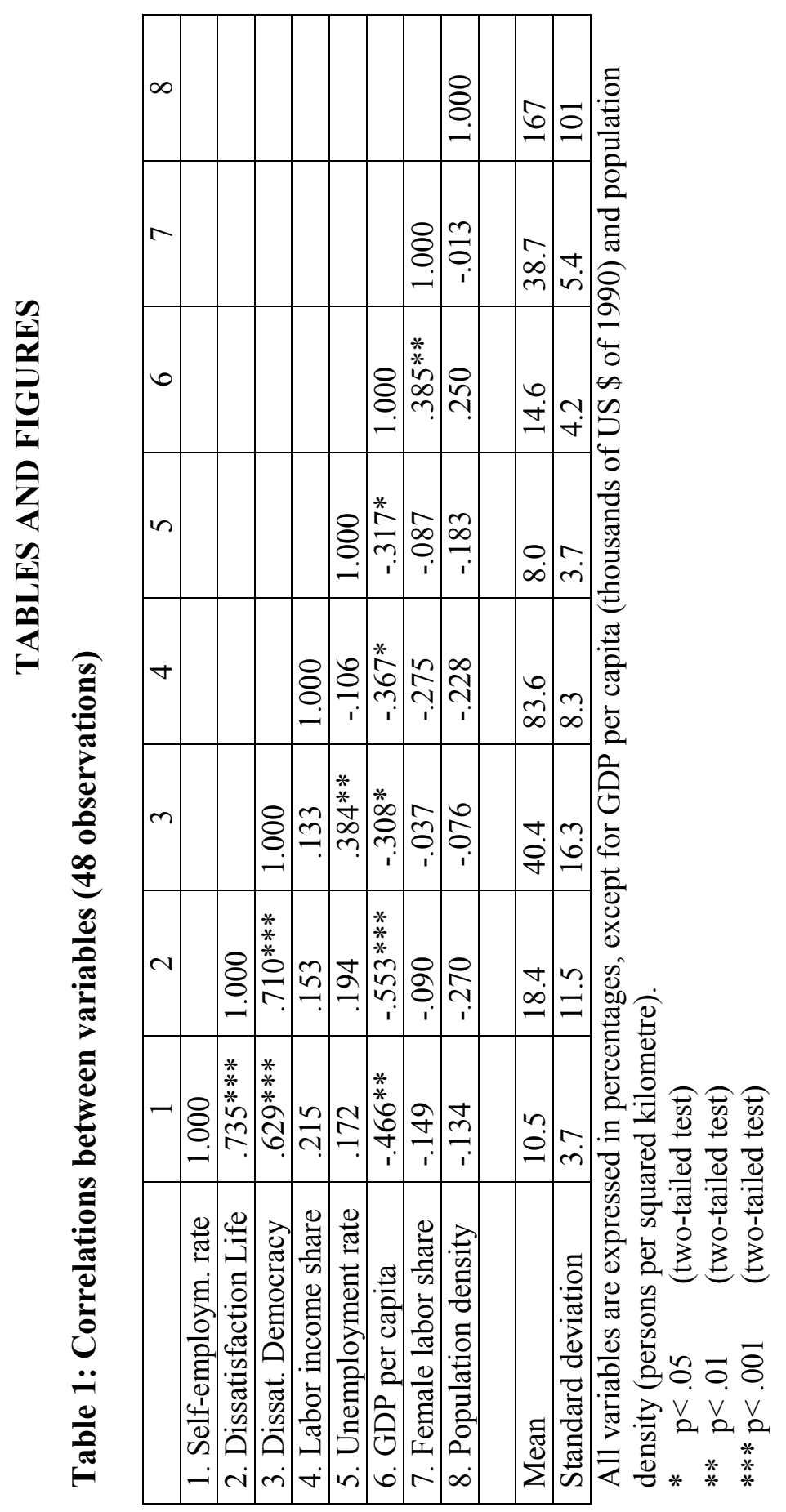



Table 2: Self-employment and dissatisfaction (48 observations)

\begin{tabular}{|c|c|c|c|}
\hline & Model 1 & Model 2 & Model 3 \\
\hline Constant & $18.3 \quad(7.3) *$ & $8.0 \quad(6.0)$ & $17.7 \quad(5.1) * *$ \\
\hline Labor income share $(\mathrm{t}-2)$ & $.069(.057)$ & $.075(.044)$ & $.025(.041)$ \\
\hline Unemployment rate $(\mathrm{t}-2)$ & $-.15 \quad(.14)$ & $-.068(.11)$ & $-.36 \quad(.10) * *$ \\
\hline GDP per capita (t-2) & $\begin{array}{ll}-.68 & (.13) * * * \\
\end{array}$ & $-.28(.13) *$ & $-.54 \quad(.097) * * *$ \\
\hline Female labor share $(\mathrm{t}-2)$ & $-.21 \quad(.099) *$ & $-.18 \quad(.076) *$ & $-.24 \quad(.070) * *$ \\
\hline Population density (t-2) & $.0064(.0046)$ & $.0074(.0035) *$ & $.0039(.0033)$ \\
\hline Year: 1986 & $2.9 \quad(1.4)^{*}$ & $1.7 \quad(1.1)$ & $3.4 \quad(1.0) * *$ \\
\hline Year: 1992 & $6.0 \quad(1.5) * * *$ & $4.7 \quad(1.2) * * *$ & $6.4 \quad(1.0) * * *$ \\
\hline Year: 2000 & $8.2 \quad(1.8) * * *$ & $5.4 \quad(1.5) * *$ & $7.5 \quad(1.3) * * *$ \\
\hline Dissatisfaction Life $(\mathrm{t}-2)$ & & $.19 \quad(.037)^{* * *}$ & \\
\hline Dissatisf. Democracy (t-2) & & & $.13 \quad(.021)^{* * *}$ \\
\hline R-squared & .528 & .725 & .769 \\
\hline Adjusted R-squared & .431 & .660 & .714 \\
\hline F-value & $5.45^{* * *}$ & $11.1 * * *$ & $14.1 * * *$ \\
\hline Maximum VIF & $4.02($ Year 2000) & $4.63($ Year 2000) & $4.05($ Year 2000) \\
\hline
\end{tabular}

Dependent variable: non-agricultural self-employed as a percentage of the labor force; standard errors between parentheses.
$* \quad \mathrm{p}<.05$
(two-tailed test)
$* * \quad \mathrm{p}<.01$
(two-tailed test)
$* * * \mathrm{p}<.001$
(two-tailed test) 